\title{
BAK1 wt Allele
}

National Cancer Institute

\section{Source}

National Cancer Institute. BAK1 wt Allele. NCI Thesaurus. Code C49366.

Human BAK1 wild-type allele is located in the vicinity of $6 \mathrm{p} 21.3$ and is approximately $8 \mathrm{~kb}$ in length. This allele, which encodes $\mathrm{Bcl}-2$ homologous antagonist/killer protein, is involved in cell death promotion and counteracts the protection from apoptosis provided by $\mathrm{BCL} 2$. 